\title{
PERTUMBUHAN MINI MARKET SEBAGAI SALAH SATU BENTUK PASAR MODERN
}

\author{
Yenli Megawati \\ Dosen Universitas Bunda Mulia, Jakarta \\ Email: ymegawati@bundamulia.ac.id
}

\begin{abstract}
The concept of Store Environment have become something of a trend around 1990 until now especially since economic crisis and interest rates on deposit accounts are not so attractive anymore besides shifting in consumer habits. The growth of mini markets as a business that adopts this concept has become really high in many parts of the world especially in Indonesia. The growth of mini markets have negative impact on local business or traditional markets but on the other hand, it also has positive impacts on job opportunities for community.
\end{abstract}

Keywords: modern market, mini markets, franchises, traditional market

\section{PENDAHULUAN}

Pasar modern di sini maksudnya adalah swalayan yang mana pelayanan dilakukan sendiri oleh konsumen karena toko tidak menyediakan pramuniaga yang khusus melayani konsumen. Hal ini jelas berbeda dengan pasar tradisional yang mana pemilik ataupun karyawan toko masih dan harus melayani konsumen. Yang termasuk dalam kategori pasar modern ini antara lain mini market, supermarket dan hipermarket.

Mini market merupakan pasar swalayan yang hanya memiliki satu atau dua mesin register saja atau sering disebut juga mesin kasir dan hanya menjual produk-produk kebutuhan dasar rumah tangga (basic necessities) yang telah dipilih terlebih dahulu, sedangkan supermarket yang juga merupakan pasar swalayan memiliki lebih dari dua mesin register dan juga menjual barang-barang segar (fresh goods) seperti sayur dan daging selain basic necessities yang juga lebih beragam daripada mini market. Hipermarket sendiri juga menjual basic necessities dan barang-barang segar yang lebih beragam dibandingkan supermarket, namun selain itu hipermarket juga menjual barang-barang white goods atau elektronik seperti mesin cuci, mesin penyedot debu, kulkas, air conditioner dan lainnya. Selain itu, hipermarket dan supermarket juga memiliki sarana perparkiran yang cukup luas yang mana luas lahan parkir dari hipermarket umumnya lebih luas dibandingkan dengan supermarket.

Pasar modern (pasar swalayan) yang saat ini semakin marak, khususnya di Indonesia, menggunakan konsep Store Environment yang berfokus pada penjualan retail (eceran) dan langsung ke konsumen akhir. Konsep ini dirancang sedemikian rupa dengan mementingkan konsep kenyamanan bagi para pengunjung sehingga para pengunjung baik dengan tujuan awal untuk berbelanja atau hanya sekedar melihat-lihat dapat terangsang menjadi konsumen dan menghabiskan waktu serta berbelanja di mini market tersebut.

Konsep Store Environment ini mulai berkembang di Indonesia sekitar tahun 90-an terutama semenjak krisis ekonomi dan tingkat suku bunga deposito tidak lagi menarik. Konsep ini mempunyai tiga konsep utama, yaitu: Store Image, Store Atmospheres, dan Store Theatres.

Disamping itu, konsep Store Environment itu sendiri mulai dipadukan dengan konsep lain, seperti sistem waralaba atau Franchise System yang mempermudah para investor lain untuk mengembangkan usaha terutama bagi investor lokal yang belum memiliki pengalaman dalam mengelola dan mengoperasikan pasar modern.

Sistem waralaba atau Franchise System ini juga mendorong pertumbuhan yang pesat dari pasar modern terutama pertumbuhan mini market dikarenakan investasi awal untuk mini market lebih rendah dibandingkan dengan investasi atas supermarket ataupun hipermarket. Jika tadinya pemilik atau investor dari mini market hanya memiliki modal untuk membuka satu atau dua gerai saja, maka dengan adanya sistem waralaba atau Franchise System ini dimungkinkan untuk membuka gerai dalam jumlah puluhan bahkan ratusan gerai.

Gerai mini market yang hanya berjumlah sedikit, misalnya satu atau dua gerai saja, memiliki posisi tawar menawar (bargaining position) yang rendah dengan produsen dan sulit untuk mendapatkan kredit dari bank. Selain itu, dengan jumlah gerai yang sedikit berarti barang-barang yang dijual di gerai tersebut akan lebih mahal karena marjin yang diterima dari produsen ataupun supplier sangat kecil. Hal ini dapat diatasi dengan mengadopsi sistem waralaba atau Franchise System yang mulai berkembang saat ini yang memungkinkan tumbuhnya gerai-gerai mini market dalam jumlah puluhan bahkan ratusan. Bahkan dengan jumlah mini market yang sedemikian banyak, justru produsen yang akan mencari mini market untuk memasarkan produknya (bargaining position menjadi tinggi). Jadi dalam hal ini, sistem waralaba juga menjadi salah satu faktor pendukung 
pertumbuhan mini market khususnya di Indonesia selain prosedur atau izin pendirian mini market yang cukup mudah di beberapa daerah.

Konsep pasar modern ini yang mementingkan kenyamanan bagi para pengunjung diperkirakan sebagian besar akan menggantikan sistem pasar tradisional. Image yang terpatri pada konsumen jika membicarakan tentang pasar tradisional umumnya adalah pasar dengan bentuk bangunan yang relatif sederhana; suasana yang relatif kurang menyenangkan seperti ruang tempat usaha atau toko yang sempit; sarana perparkiran yang kurang memadai; kebersihan pasar yang tidak terjaga (bau, becek, kotor) sehingga tidak memungkinkan bagi konsumen untuk berbelanja ke pasar dengan berpakaian rapi (jas, dasi, dan sebagainya); serta penerangan yang kurang baik. Barang-barang yang diperdagangkan di pasar tradisional adalah barang kebutuhan sehari-hari dengan mutu barang yang kurang diperhatikan; harga barang relatif murah namun cara pembeliannya masih dengan menggunakan sistem tawar menawar (bargaining) yang cukup menyita waktu. Para pedagangnya sebagian besar adalah golongan ekonomi lemah dengan cara berdagang yang kurang profesional. Contoh pasar tradisional seperti pasar Inpres, pasar lingkungan, dan sebagainya.

Berdasarkan pemaparan mengenai pasar modern dan pasar tradisional di atas, dapat disimpulkan bahwa saat ini pada umumnya yang menghuni pasar modern adalah para pedagang yang tergolong pengusaha menengah atas sedangkan pasar tradisional dihuni oleh para pedagang yang tergolong pengusaha menengah bawah dan mikro. Keduanya memperebutkan pangsa pasar sektor perdagangan retail yang relatif sama karena menjual ragam produk yang relatif sama walaupun dengan tingkat harga dan kenyamanan yang berbeda.

Khusus untuk mini market, salah satu jenis pasar modern yang saat ini sedang berkembang pesat, menawarkan kemudahan karena lokasi toko atau gerai yang dekat ke konsumen di perumahan-perumahan. Luas dari toko atau gerai tidak terlalu besar, sekitar 90-150 meter persegi dan menjual 3.000-4.000 item barang. Mini market tidak terlalu membutuhkan investasi besar dan sebagian besar pangsa pasarnya adalah perorangan dan ibu-ibu rumah tangga terutama mereka yang bekerja dan mengutamakan kepraktisan dan kecepatan atau waktu yang tidak lama dalam berbelanja.

Selain beberapa hal di atas, terdapat beberapa keuntungan lain dengan berbelanja di mini market yaitu suasana nyaman dan aman dalam berbelanja; mudah dalam memilih barang-barang yang diperlukan; kualitas barang lebih terjamin dibandingkan berbelanja di pasar tradisional; harga barang sudah pasti sehingga tidak perlu tawar menawar lagi; dan dapat berbelanja berbagai keperluan dalam satu tempat saja sehingga akan menghemat waktu dan tenaga. (Harmaizar, 2006: 327-328).

\section{PERTUMBUHAN MINI MARKET DI INDONESIA}

Peran pasar modern khususnya mini market di Indonesia kian hari kian besar dan diperkirakan pada akhirnya akan menggeser pasar tradisional. Hal ini terjadi karena adanya pergeseran preferensi konsumen yang dalam hal ini adalah preferensi dalam berbelanja. Untuk itu, perlu disadari bahwa setiap konsumen memiliki kebutuhan yang berbeda. Menurut Levy and Weitz (2004: 112-113), kebutuhan konsumen dapat diklasifikasikan atas dua kategori yaitu:

a. Kebutuhan fungsional (functional needs), kebutuhan ini berhubungan langsung dengan bentuk atau penampilan (performance) dari produk.

b. Kebutuhan psikologis (psychological needs), kebutuhan ini diasosiasikan dengan kebutuhan yang bersifat mental dari konsumen yang dapat terpenuhi dengan berbelanja ataupun membeli dan memiliki sebuah produk.

Banyak produk yang dapat memenuhi kebutuhan fungsional sekaligus kebutuhan psikologis. Dengan semakin tingginya tingkat pendapatan konsumen maka kebutuhan psikologis akan semakin tinggi juga. Hal inilah yang menyebabkan kebutuhan akan kenyamanan berbelanja, jasa yang baik, produk-produk yang bermerek dan trendi lebih penting bagi konsumen di perkotaan misalnya dibandingkan dengan konsumen di pedesaan yang tingkat pendapatannya jelas berbeda.

Selain itu, perilaku konsumen dalam membeli produk juga menjadi salah satu alasan semakin berperannya mini market (pasar modern). Menurut Kurt Salmon Associates (Berman and Evans,2004: 170), terdapat sepuluh alasan teratas yang menyebabkan konsumen atau pengunjung meninggalkan gerai tanpa membeli sebagai berikut:

a. tidak dapat menemukan gaya atau bentuk yang menarik

b. tidak dapat menemukan ukuran yang apas ataupun gerai tersebut sedang kehabisan produk (out of stock)

c. tidak ada yang cocok

d. tidak ada karyawan yang dapat ditanya mengenai produk

e. tidak dapat keluar masuk dari gerai dengan mudah

f. harga terlalu tinggi

g. situasi di dalam gerai atau toko tidak nyaman

h. tidak dapat menemukan nilai yang baik

i. tata letak di dalam gerai tidak diatur dengan nyaman

j. produknya sedang tidak musim 
Sebagian besar alasan-alasan di atas dapat teratasi dengan berbelanja di mini market (pasar swalayan) yang mengutamakan konsep kenyamanan bagi konsumen termasuk di dalamanya kelengkapan produk yang dalam hal ini adalah produk-produk dasar kebutuhan rumah tangga bagi mini market, tata letak produk yang baik dan tidak campur aduk, lokasi yang dekat dengan pemukiman, dan harga yang tidak terlalu tinggi.

Preferensi masyarakat dalam memenuhi kebutuhan sehari-harinya juga semakin hari semakin bergeser. Hal inilah yang menyebabkan penurunan pertumbuhan pasar tradisional dan semakin tingginya perkembangan mini market yang merupakan salah satu bentuk dari berbagai macam pasar modern. Dulu, masyarakat cenderung untuk berbelanja kebutuhan sehari-hari di pasar-pasar tradisional namun sekarang masyarakat cenderung berbelanja di pasar-pasar modern.

Alasan pergeseran preferensi konsumen tersebut sebagian besar disebabkan lebih nyaman untuk berbelanja di mini market karena tidak becek, bau dan kotor; selisih harga yang tidak terlalu jauh berbeda antara mini market dengan pasar tradisional; harga produk yang tetap (fixed price) yang berarti tidak perlu tawar menawar antara konsumen dengan pemilik yang mana hal ini juga berarti menghemat waktu dalam berbelanja; lokasi mini market yang semakin dekat dengan perumahan-perumahan sehingga lebih mudah dijangkau oleh masyarakat serta adanya beragam produk yang dijual di satu gerai yang berarti lebih praktis dalam berbelanja.

Berdasarkan riset yang dilakukan oleh Masterlndeks pada tahun 2005, pertumbuhan penjualan ritel di Indonesia mencatat angka terbesar seAsia-Pasifik yaitu mencapai 16,9 persen per tahun atau sebesar Rp 166 triliun. Angka ini merupakan angka yang terbesar se-Asia Pasifik. Berikut urutan pertumbuhan ritel setelah Indonesia yakni Cina (12,75 persen atau 2,85 triliun Yuan); Thailand (12,3 persen atau 1.059 miliar Baht); Malaysia (8,9 persen atau 30 miliar Ringgit), Hong Kong (8,7 persen atau HK\$ 99 miliar); Filipina (8,5 persen atau 331 miliar peso); Singapura (6,5 persen atau SG\$ 14,3 miliar); Selandia Baru (5,5 persen atau NZ\$ 16,2 miliar); Taiwan (4,8 persen atau NT\$ 1,519 miliar); Australia (4 persen atau A $\$ 85$ miliar); Jepang (2,3 persen atau 56 triliun Yen) dan Korea (1,78 persen atau 64 triliun Won). Biasanya Masterlndeks melakukan riset dua kali setiap tahunnya yaitu di bulan Juni dan Desember (http://detikinet.com).

Pertumbuhan ritel di Indonesia tercermin dengan pesatnya pertumbuhan mini market sebagai salah satu pasar modern dan ritel di Indonesia. Pada kurun waktu 2002-2006, mini market tumbuh rata-rata $29 \%$ per tahun. Gerai-gerai mini market yang tadinya hanya berjumlah ratusan di tahun 2002 melonjak menjadi ribuan di tahun 2006. Hal ini jelas terlihat dengan bermunculannya gerai-gerai mini market dalam radius setidaknya 500 meter dan kini telah memasuki pemukiman-pemukiman padat bahkan kompleks-kompleks perumahan.

Menurut Yongki, Direktur Pengembangan Ritel dan Bisnis ACNielsen Indonesia, persentase pangsa pasar tradisional akan semakin mengecil sedangkan pangsa pasar modern akan semakin tinggi sampai pada saatnya persentase kedua pasar tersebut seimbang. Karena bagaimanapun, tetap akan ada masyarakat yang loyal untuk berbelanja di pasar tradisional.

Pasar modern masih memiliki peluang yang cukup besar untuk makanan segar (fresh foods) karena penjualannya yang belum maksimal. Selama ini, konsumen Indonesia masih menjadikan pasar tradisional sebagai pilihan utama untuk membeli barang-barang segar. Khusus untuk mini market yang menjual makanan segar dalam ragam yang terbatas, umumnya hanya tiga sampai dengan lima jenis buah-buahan, peluang untuk bersaing dalam produk ini terbilang cukup besar dikarenakan adanya kecenderungan dari masyarakat yang lebih senang berbelanja buah-buahan di pasar swalayan karena kualitas yang lebih terjaga dengan adanya fasilitas pendingin.

\section{DAMPAK MENJAMURNYA MINI MARKET}

Dengan semakin banyaknya jumlah gerai-gerai mini market di pemukiman-pemukiman penduduk, tentunya hal tersebut memiliki dampak baik dampak yang bersifat positif maupun yang bersifat negatif.

Semakin menjamurnya mini market akan mematikan pedagang-pedagang kecil atau setidak-tidaknya menurunkan penjualan dari pedagang-pedagang kecil terutama para pedagang yang berlokasi di sekitar mini market dan memperdagangkan komoditi sejenis. Dengan semakin menurunnya pangsa pasar dari pedagangpedagang kecil maka upaya pemberdayaan masyarakat melalui berbagai program sebagai upaya membantu masyarakat ekonomi lemah yang mana biasanya bantuan yang diterima oleh pedagang-pedagang kecil adalah dalam bentuk warung-warung kecil dan hal tersebut menjadi kurang berguna karena penurunan pangsa pasar yang terjadi.

Selain itu, semakin banyaknya gerai-gerai mini market juga dapat menyebabkan kecemburuan sosial terutama dari pedagang-pedagang kecil yang terancam usahanya.

Namun, dengan semakin banyaknya gerai-gerai mini market yang dibuka maka penyerapan tenaga kerja juga akan semakin besar yang mana jumlah tenaga kerja pada satu gerai mini market paling tidak bisa mencapai lima orang tenaga kerja sedangkan penyerapan tenaga kerja untuk satu warung kecil paling tidak hanya berkisar dua orang tenaga kerja. Hal ini berarti pembukaan satu mini market juga akan menyerap tenaga kerja yang besar.

Bagi pemerintah daerah, kesempatan yang diberikan bagi para investor untuk membuka gerai-gerai mini market juga memiliki dampak yaitu meningkatkan sederetan pos pemasukan yang dapat menunjang 
pendapatan asli daerah (PAD). Mulai dari izin mendirikan bangunan jika gerai dibuka dengan membangun bangunan baru, izin usaha, pajak bumi dan bangunan (PBB), pajak pendapatan dari toko dan gerai, pajak reklame indoor dan outdoor, retribusi parkir, dan lain-lain. Pemerintah daerah mengharapkan dengan pembangunan pertokoan atau pusat perdagangan dapat meningkatkan sektor ekonomi sehingga dapat mendukung pertumbuhan sektor-sektor non ekonomi lainnya seperti pendidikan dan kebudayaan.

Dampak lainnya adalah kesempatan berinvestasi bagi para investor terutama bagi investor lokal yang belum berpengalaman dalam mengelola bisnis retail seperti mini market. Dengan kemudahan prosedur perizinan untuk memulai bisnis maka akan banyak sekali investor yang tertarik selain karena modal investasi untuk mini market tidak terlalu besar dan dimungkinkan untuk mengambil kredit dari bank. Dengan terpacunya masyarakat untuk memulai bisnis atau berwirausaha maka keterampilan masyarakat dalam berbisnis juga dengan sendirinya akan semakin terasah seperti pengetahuan akan aspek distribusi dan pemasaran sehingga tidak terbatas pada aspek dagang saja. Hal ini juga menjadi salah satu upaya dalam pengentasan kemiskinan karena dengan semakin sulit dan kompetitifnya persaingan dalam mencari lowongan pekerjaan serta tingkat UMR yang rendah sehingga tidak dapat memenuhi kebutuhan hidup maka masyarakat didorong untuk berusaha dan mandiri.

Dukungan tersebut juga diberikan oleh pemerintah melalui kemudahan pengambilan kredit sehingga tidak tertutup kemungkinan bahwa mini market dapat dikelola oleh pengusaha golongkan ekonomi menengah bawah namun tentunya harus memperhitungkan kemampuan dan keterampilan dalam pengelolaan bisnis tersebut.

\section{PENUTUP}

Fenomena pergeseran pola konsumsi masyarakat dari pasar tradisional ke pasar modern khususnya mini market yang saat ini sangat dekat dengan masyarakat di perumahan-perumahan ataupun pemukimanpemukiman padat penduduk tidak bisa dihindari. Oleh karena itu, para pedagang kecil yang terkena dampak negatif dari semakin menjamurnya mini market harus sudah mulai mengantisipasinya dengan mengikuti fenomena tersebut yaitu dengan mulai berdagang dengan menggunakan konsep inti dari pasar modern ataupun berperan sebagai produsen.

Para pedagang kecil yang masih tetap ingin menjual secara tradisional harus mencari cara untuk mempertahankan kelangsungan usahanya karena bagaimanapun akan tetap ada masyarakat yang loyal untuk berbelanja di pasar tradisional dengan berbagai alasan misalnya karena memang ingin dilayani, ada kepuasan tersendiri jika melakukan tawar menawar, kepuasan dalam bertegur sapa dengan penjual apalagi penjual yang sudah lama dikenal, dan lainnya. Merujuk pada tipe masyarakat yang loyal berbelanja di pasar tradisional maka langkah yang dapat ditempuh oleh para pedagang kecil tersebut tentunya harus memberikan nilai tambah untuk pasar tradisional terutama dalam sentuhan humanis yang tidak akan ditemukan di mini market ataupun pasar modern lainnya misalnya pemberitahuan oleh pedagang kepada konsumen jika ada produk baru, produk yang lebih bagus, produk yang lebih murah, dan lainnya.

\section{REFERENSI}

Berman, Barry dan Evans, Joel R, (2004). Retail Management A Strategic Approach. Ninth Edition. New Jersey: Pearson Education International.

Harmaizar, dkk. (2006). Menggali Potensi Wirausaha - Feasibility Study Plus and Implementation. Bekasi Utara: CV Dian Anugerah Prakasa.

http://www.pikiran-rakyat.com tanggal 2 September 2002.

http://www.sinarharapan.co.id tahun 2003.

http://www.tempointeraktif.com tanggal 19 Agustus 2004.

http://www.rsi.sg tahun 2003.

http://detikinet.com tanggal 29 Maret 2005.

Levy, Michael dan Weitz, Barton A, (2004). Retailing Management. International Edition. New York: McGraw Hill.

Tang, Angie dan Lim, Sarah, (2004). Retail Operations. Singapore: Prentice Hall.

Sujana, Asep ST, (2005). Manajemen Ritel Modern. Edisi Pertama. Graha IImu. 